\title{
Systemically important financial institutions in Latin America - A Primer
}

\author{
Instituições financeiras sistemicamente \\ importantes na América Latina
}

JACOB KLEINOW

MARIO GARCIA MOLINA

ANDREAS HORSCH*

RESUMO: As instituições financeiras mostram uma exposição de risco e vulnerabilidade característica, tornando-as propensas à instabilidade. Os sistemas financeiros da América Latina, no entanto, ficaram praticamente incólumes pela crise financeira mundial a partir de 2008. Esta pesquisa state-of-the-art fornece uma análise aprofundada sobre a identificação e regulamentação das instituições financeiras sistemicamente importantes (IFSI). Apesar da América Latina se beneficiar de sua rica experiência histórica na gestão de riscos sistêmicos, acreditamos que o problema das IFSIs é ainda subestimado. No entanto, existem primeiros esforços para lidar com as IFSIs na ciência, e particularmente os supervisores e reguladores latino-americanos estão começando a levar a sério a ameaça representada pelas IFSIs.

PALAVRAS-CHAVE: América Latina; IFSI; risco sistêmico; too-big-to-fail; instabilidade; regulamentação bancária.

ABSTRACT: Financial institutions show a characteristic risk exposure and vulnerability, making them prone to instability. Financial systems in Latin America, however, were left largely unscathed by the global financial crisis starting in 2008. This state-of-the-art survey provides an in-depth analysis on the identification and regulation of systemically important financial institutions (SIFIs). While Latin America benefits from its rich historical experience in managing systemic risks, we find the problem of SIFIs to be still underestimated. However, there are first efforts to cope with SIFIs in science and particularly Latin American supervisors and regulators are starting to take the threat posed by SIFIs seriously.

KEYWORDS: Latin America; SIFI; systemic risk; too-big-to-fail; instability; banking regulation. JEL Classification: F3; G01; G21; G28.

\footnotetext{
* Research associate, Freiberg Technische Universität Bergakademie, Germany and Universidad Nacional, Bogotá, Colombia, e-mail: Jacob.Kleinow@bwl.tu-freiberg.de; Professor, Universidad Nacional, Bogotá, Colombia, e-mail: mgarciamo@unal.edu.co; Professor Freiberg Technische Universität Bergakademie, Germany, e-mail: andreas.horsch@bwl.tu-freiberg.de. Submitted: 2/June/2014: Approved: 19/May/2015.
} 


\section{INTRODUCTION}

Financial institutions and their creditors are usually treated differently than most other firms and creditors. The reasons lie in a "perceived uniqueness of bank services and the chance that one bank's failure can spill over and threaten the viability of other banks" (Stern and Feldman, 2004, p. 12). While any bank's failure is regarded potentially contagious in general, some banks are of particular systemic importance, as their failure would have exceedingly severe repercussions not only on the banking industry. Remarkably - and unlike in the past - the financial systems of the Latin American countries turned out to be safe havens during the years of turmoil succeeding Lehman's bankruptcy. There are several major reasons for Latin America's relative stability during the great financial crisis. To some extent Latin American countries benefited from experience that had been learnt from (crises of) the past (Bresser-Pereira, 2010b). Additionally, Latin American countries have (had) a somewhat different approach to financial oversight. Moreover, the credit cycle was not as pronounced as in the industrialized countries and public and private sector balance sheets were stronger than during former crises (BresserPereira, 2010b, as well as Gutierrez and Caraballo, 2011). It is precisely for those reasons that the existence of and dealing with systemically important financial institutions (SIFIs) in Latin America has been underestimated lately. Our survey aims at helping to fill this scientific gap by analysing the state of affairs of identifying and regulating SIFIs in Latin America.

The survey is structured as follows: first, we summarize the role of financial institutions in Latin America during crises from a historical background in second section. We then discuss idiosyncratic characteristics of financial institutions and explain what distinguishes them from financial firms. Third section is about the identification of SIFIs: various approaches from academia and international regulators are explained. Based on that, we give a comprehensive overview of Latin American literature on the assessment of SIFIs. Fourth section explores regulatory innovations aiming at SIFIs; again, first from a theoretical point of view, then from the perspective of international policy makers and, at last, based on Latin American regulations. Last section concludes.

\section{THE PROBLEM OF (IN)STABILITY OF FINANCIAL SYSTEMS IN LATIN AMERICA}

\section{The general problem}

Instability in the financial sector plays a key role in the instability of the macroeconomy, as can be seen in the financial instability hypothesis (Minsky, 1975, 1982, 1992). The key point of this explanation is that crises are an intrinsic feature of capitalistic economies, as the optimism fuelled in periods of prosperity leads to bubbles and instability. We in general consider this inbuilt instability on a systemic 
level first, before turning to problems of instability on an institutional level. Main components of a financial system are the financial intermediaries and the rules and organizations designed to regulate and supervise them. Based hereupon, systemic risk can be seen as "a risk of disruption to financial services that is (a) caused by an impairment of all or parts of the financial system and (b) has the potential to have serious negative consequences for the real economy" (BIS, FSB and IMF, 2009, p. 2).

Minsky's theoretical explanation of systemic crises was applied to the main historical financial crises by Kindleberger (2005), and to the 2009 US crisis by Yellen (2011). His approach stresses that the fundamental instability of a capitalist economy is upwards, but also that crises are a by-product of it. This amounts to say that systemic risk will increase during a boom but there is still room for prudential policy. On the other hand, banks play a key role regarding ignition or spreading of a financial crisis, as is discussed hereafter. The systemic risk literature has advanced in analyses of both respects recently.

Several Latin American crises could be well described by Minsky's model on financial stability (Bresser-Pereira, 2010a). ${ }^{1}$ The number and intensity of crises within the continent has diminished since 1998. Still, the extended period of prosperity in Latin America poses a good opportunity to identify possible weak spots that might eventually turn out important to the system. This paper surveys the recent Latin American literature on how to identify and regulate SIFIs in Latin America.

\section{The particular problem of financial organizations}

While approaches to define financial systems vary, they agree upon (1) financial intermediaries and (2) financial regulation being core parts of it. In a narrow sense, financial intermediaries in general, and banks in particular, are regarded to be the financial system. Their proper functioning is crucial for the system's (in)stability, as the failure of just one bank is able to destabilize the entire structure. This apprehension is based on their financial intermediary role: Unlike other industries, banks have small-scale depositors with short-term contracts, for whom the bank and its investments are opaque (Diamond, 1984; Diamond and Dybvig, 1983). As banks' equity is comparably low, too, they face a characteristic kind of insolvency risk: bank depositors are expected to panic easily. Their run on the bank is expected to be fatal because of a combination of insufficient liquidity to meet all withdrawal demands and losses incurred during subsequent fire sales of bank assets. Due to the fact that banks form a closely-knit network, a run on one bank will not remain an isolated event, but will contagiously affect further banks.

While the previous reasoning is at the heart of traditional attempts to prove

\footnotetext{
${ }^{1}$ Prior to the 1994 Tequila Effect, for instance, Mexico experienced a rise in credit volumes to the private sector at low interest rates, fuelled by foreign credit although public credit had previously been decreased. When political turmoil led to increased interest rates, the government had severe difficulties to maintain the fixed exchange rate and the confidence of investors. Then the crisis exploded and affected most Latin American countries (Dabrowski, 2001).
} 
that banks are special - and thus call for special regulatory treatment (see Benston, 1998), it has been challenged seriously by no lesser than the recent financial crisis, which saw several banks defaulting that were of more than average size, importance, and interconnectedness. ${ }^{2}$ Although less extensively researched and discussed, insurance companies and other financial companies share the characteristics of protection-worthy, nervous customers, the vulnerability to noise, and the connectedness, making them prone to contagion or run phenomena as well (Acharya et al., 2009; also Fenn and Cole, 1994), so that SIFIs are not just banks.

As financial crises habitually drive financial regulation, it comes as no surprise that parts of recent re-regulation aim at organisations that are considered to be "systemically important". A comprehensive stock-taking of current regulatory initiatives shows that this regulation is focused on, but not limited to, banks. Unfortunately, systemic importance will be a guess by definition, hopefully an educated one: if a particular financial intermediary could destabilize the system, it will only be known after it has done so, but not ex ante. Not surprisingly, approaches to define SIFIs vary, too, leading to the particular question which kind of SIFIs and SIFI-regulation can be found in Latin America.

\section{The particular problem of financial regulations}

The second important part of any financial system, besides financial firms, is its institutional framework, i.e., the "rules of the game" (North, 1990). While general rules of behaviour are unquestioned, specific governmental involvement in market processes by means of regulation should be carefully justified as it might replace a market failure by a government failure. Thus, regulation is deemed appropriate if (a) market failure occurs that can be expected to be solved (b) effectively and (c) efficiently by the introduction of a certain regulation (e.g., Skipper and Klein, 2000).

(Well intended) Regulation is an attempt to governmentally manage the importance and destabilizing potential of particular players, thus to provide a solution to the serious problem of financial (in)stability. Unfortunately, regulation should not be expected to be so perfect (Rugitsky, 2014), as rule makers and regulators are (self-interested) human actors, too:

It should be noted that the public choice about whether and to what extent financial services, firms and markets should be regulated is not between a perfect regulator who acts to secure the public good and perfect markets that regulation can only worsen. Both are staffed and managed by people who tend to act to maximize and secure their own welfare, sub-

\footnotetext{
${ }^{2}$ Probably, the insolvency of Lehman Bros. will remain the most outstanding case regarding size, speed, surprise, and consequence, see e.g. Brunnermeier (2009); Summe (2009).
} 
ject to various constraints (such as ability, tastes, ethics and costs imposed by others). Consequently, both are imperfect (Benston, 1998, pp. 1-2).

Even more unfortunately, ill-designed regulation causes more harm than failing to correct the market failure it was aimed at, as any regulation affects incentives and subsequent human action. Being part of the (unwritten) regulatory framework, too-big-to-fail doctrines that preceded current regulatory approaches towards SIFIs already prove this two-sidedness of regulation: while meant to enhance depositor protection and system stability, they incentivise creditors of large banks to assume that the government will limit their insolvency costs. This leads them to reduce their corporate control activities, letting management agents opt for higher-risk-higherreturn opportunities, thus increasing the bank's default probability, while risk exposure is shifted from stakeholders of the bank to the general public. Perceiving this scenario, regulators tend to re-regulate. Thus, particularly crisis-driven rule making and regulation should be reviewed thoroughly, as crises offer not only perfect public welfare justifications for regulation, but perfect conditions for selfinterested action of rule makers and regulators, too (whose reasoning and actions probably include less rational, more behavioural patterns).

Therefore, parts of the SIFI-problem are a regulatory problem, too, which is why our research of SIFIs in Latin American encompasses these intermediaries as well as their regulatory framework.

\section{ASSESSING THE SYSTEMIC IMPORTANCE OF FINANCIAL INSTITUTIONS IN LATIN AMERICA}

\section{Why financial systems in Latin America are different - A comparison with wealthier economies}

Although the differences between financial systems within Latin American countries are quite remarkable, some similarities can be drawn and then compared with richer economies. Historically, financial systems in Latin American countries have always been developed to a lesser degree (or "simpler") and are still less market oriented (Stallings and Studart, 2006). Being less globally integrated, Latin American financial markets remained stagnant until the 1990s, when financial intermediation by both financial institutions and capital markets increased exponentially. This was supported by a capital wave that waned before the turn of the century and came back in 2003. Technological progress was made and financial flows increased along with the flow of goods among Latin American countries (Bresser-Pereira, 2010a). In the following years Latin America coped with own regional crises that interestingly had only weak contagion effects (Agnoli and Vilàn, 2008). One major reason for that can be seen in comparably stricter prudential capital regulations for Latin American banks. Regulations were less harmonized and appeared less sophisticated than Basel II (and later Basel III) requirements, but 
fulfilled their aim. The lack of harmonization turned into a positive effect of regulatory diversification: The capital outflows during the great financial crisis were weathered much better than in the rest of the world (Gutierrez and Caraballo 2011). The following Figure 1 summarizes reasons for the relative resilience of Latin American financial systems as seen by their supervisors and central bank representatives. One of the main reasons is that banks had far less invested in structured assets like subprime US-RMBS assets or any other securities issued securities that turned out "toxic" (Bresser-Pereira, 2010b).

Figure 1: What Latin American supervisors and central bank representatives think (Gutierrez and Caraballo, 2011)

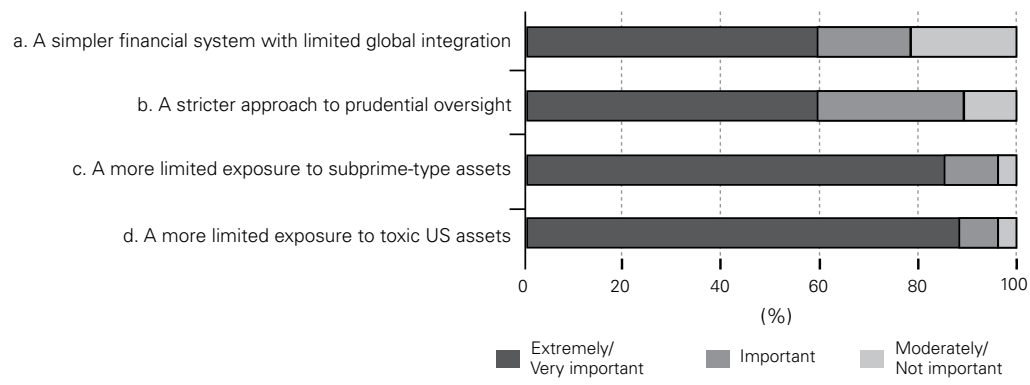

Responds of Latin American supervisors and central bank representatives to "Please rate the factors underlying the possible relative resilience of your financial system, compared to that of the countries in the world that were the most affected".

One could question if the financial resilience of Latin American financial systems during the great financial crisis was fortune or a reward for good policies. One of the next systemic crises, however, could as well come not from outside, but from inside the Latin American sphere. In any respect, it seems appropriate to counterbalance the particular importance of SIFIs by particular policies to keep contagious processes at bay, including suitable legal and procedural arrangements to identify drivers of systemic risk, to measure and minimize systemic importance as well as to orderly resolve a failing SIFIs.

\section{Measures of SIFIs and systemic risk in empirical finance}

The initial point for identification of SIFIs in academia is the assessment of the impact (negative external effects) an insolvency of an institution would have on the financial system and subsequently the real economy. However, this simple question is difficult to answer since failures of large financial institutions do not occur frequently - what makes it difficult to forecast what would happen if such an institution either fails or is bailed out. Therefore, more than one risk measure is usually necessary and is used to capture at least some proportion of systemic risk. Apart from that, it may not be desirable from a scientific viewpoint to search for a single consensus measure for SIFIs because a lack of diversification would 
invite blindsided surprises (Bresser-Pereira, 2013). Bisias et al., provide a survey of 31 quantitative systemic risk measures and recognise "that the most useful measures of systemic risk may be ones that have yet to be tried because they require proprietary data only regulators can obtain" (Bisias et al., 2012, p. 4). It is therefore obvious why scholars use model based measurement approaches that only require price data (of stocks, bonds, CDS) from securities markets as inputs. The steadily growing academic literature on systemic risk of financial institutions can be divided into the (1) risk contribution-and the (2) risk participation-stream (see Figure 2).

Scholars dealing with the (1) risk contribution of a financial institution try to determine systemic importance by measuring a single institution's contribution to systemic risk. According to this understanding, it is of special interest to avoid and mitigate contagion effects. The data mainly used by scholars comprises measures on size, connectedness, and substitutability of a financial institution. Popular applications of the risk contribution approach are (a) the $\Delta$ CoVar, (b) the CoRisk, (c) Granger Causality Networks and (d) the Principal Component Analysis. (a) $\triangle \mathrm{CoVar}$ "captures the marginal contribution of a particular institution (in a non-causal sense) to the overall systemic risk" (Adrian and Brunnermeier, 2011, p. 2) by applying quantile-regressions. (b) CoRisk analyses the tails of the distributions of defaults of pairs of institutions, or - to put it simply - it analyses how the default risk of an institution is affected by the default risk of another institution (IMF, 2009). (c) The Granger Causality approach measures the directionality of relationships or causality of price movements of securities issued by financial institutions (Billio et al., 2012). (d) The Principal Component Analysis (PCA) is a technique to decompose asset returns of a sample of financial institutions into linkages between those institutions (ibidem). Conversely designed academic papers dealing with the (2) risk participation try to determine systemic importance by measuring to what extent a single institution is affected in case of a systemic event. To maintain the overall functioning of the (financial) system and maximise survivorship is the idea of this approach. The data mainly used by scholars in the case of risk participation comprises measures on credit exposure/ spreads, interest rates, leverage, and solvency buffers.

This table provides an overview of the steadily growing academic literature on systemic risk of financial institutions. Current scholarly approaches can be divided into the (1) risk contribution- and the (2) risk participation-stream. For description and application of the measures see: a: Adrian and Brunnermeier (2011), b: IMF (2009), c: Billio et al. (2012), d: Billio et al. (2012), e: Acharya et al. (2010), f: Brownlees and Engle (2012), g: Jobst and Gray (2013), h: Weiß et. al. (2014) 
Figure 2: Approaches to identify SIFIs

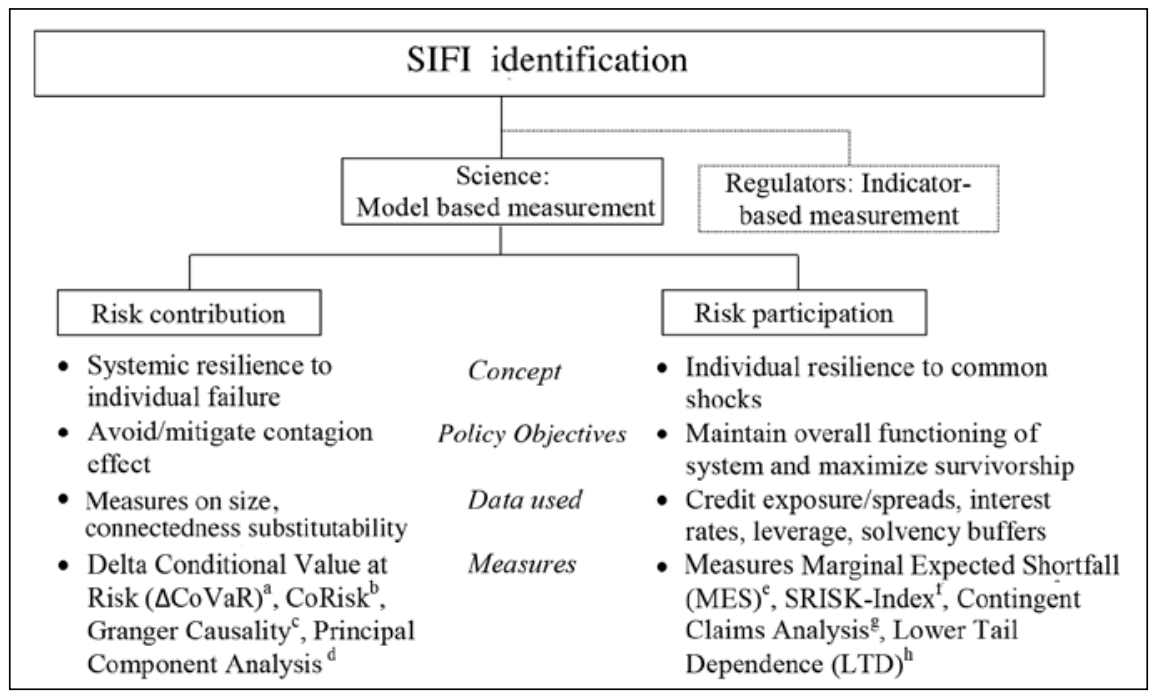

For description and application of the measures see:

a: Adrian and Brunnermeier (2011)

e: Acharya et al. (2010)

b: IMF (2009)

f: Brownless and Engle (2012)

c: Bellio et al. (2012)

d: Bellio et al. (2012)

g: Jobst and Gray (2013)

h: Weiss et al. (2014)

Source: Own illustration following Weistroffer (2011), and Jobst \& Gray (2013).

Popular applications of the risk participation approach are (e) the Marginal Expected Shortfall, (f) the SRISK-Index, (g) the Contingent Claims Analysis and (h) the Lower Tail Dependence. (e) The Marginal Expected Shortfall (MES) determines the level of systemic risk by measuring an institution's losses (in terms of negative index returns) when the (financial) systems as a whole is doing poorly (Acharya $e t$ al., 2010). (f) SRISK proposed by Brownlees and Engle (2012) is a powerful index formed by the leverage, size and the MES of a firm. (g) The Contingent Claims Analysis measures systemic solvency risk based on market-implied expected losses of financial institutions by generating aggregate estimates of the joint default risk of multiple institutions as a conditional tail expectation (Jobst and Gray, 2013). (h) The Lower Tail Dependence (LTD) is a measure of the propensity of a single financial institution to experience joint extreme adverse effects (measured in price returns) with the market (Weiß et al., 2014).

\section{SIFIs and systemic risk in Latin America}

As the Latin American financial sector did not face any severe market turmoil comparable to the US or the EU in the financial crisis since 2007, the existence of SIFIs has only recently become perceived as a particular problem, so that research is scarce so far and direct comparisons of systemic risk drivers in Latin America and wealthier economies have not been drawn yet. On the other hand, extensive research 
regarding bank failures and systemic risks during the reform periods and financial liberalisation in the 1990s has been conducted. Consequently, existing literature on systemic importance in Latin America can be divided into two streams: (a) Earlier studies mainly assessing the individual risk of Latin American financial institutions (including extensions to - rather fragmentary - measures of systemic risk), and (b) current studies that primarily assess the systemic importance by means of distinguished methods explained in the above section. Online Appendix Table 2 provides a comprehensive overview on Latin American literature including the methodologies used, country and time coverage, data sources and (SIFI specific) estimation results..

Typically, earlier studies on banking failure and systemic character of banks in Latin America use survival analysis methods (based on data comparison of financial statements of banks that failed in a crisis or survived it) to estimate the influence of certain bank characteristics on banking fragility and to forecast the time duration to until a bank fails. For Venezuela, Molina (2002) discovers that both a bank's ability to generate sound profits and a high exposure to low risk government bonds are important drivers for stability during a crisis. Another main result is that banks are less likely to fail when they are big (in terms of assets), have lower financial expenses, and comparatively higher returns on investments. A comparable study on a large US bank sample by Alali and Romero (2013) confirms the findings on profit. However, the study also shows that in the US the size of a bank has no influence on risk and older banks as well as banks with high real estate, agricultural and non-performing loans are more likely to fail. González-Hermosillo, Pazarbaşioğlu and Billings (1997) develop a banking sector fragility index and test it with data on Mexican financial institutions: Their results show that a high level of nonperforming/ nonsecuritised loans, interbank deposits, interest rates, and a depreciation of the exchange rate (Mex. Peso/\$ US) increase fragility of the banking sector. In the case of banks in Colombia, Lozano and Guarín (2014) find that foreign credit, wholesale funding and high interbank exposures drive banking system instability. This goes in line with Bresser-Pereira and Gala (2007) explaining why current account deficits (foreign savings) in capital poor medium income countries, financed either by loans or by foreign direct investments, will not usually increase the rate of capital accumulation. Especially popular is the regression of CAMEL(OT) fundamentals (on Capital adequacy, Asset quality, Management, Earnings, Liquidity, Operational controls and Technology) on banks individual risks (see Crystal et al., 2001 and Molina, 2002). By applying rather descriptive statistics, Crystal et al. find that foreign banks operating in Argentina, Chile and Colombia provide important positive influences on the stability and development of the respective banking system.

After half a decade of little concern for banking failure and systemic importance in Latin America, Arena (2008) and Daley et al. 2008 use comparable methods for determining characteristics of contribution of bank-level fundamentals on failing/ surviving banks. Arena (2008) observes that big banks in Argentina, Chile, Colombia, Mexico, Peru and Venezuela are less likely to fail. He explains that with an implicit TBTF status banks are rewarded, and the assumption of better diversification in larger portfolios. Interestingly for the case of Jamaica, (Daley et al. 2008) 
come to the contrary conclusion, i.e., that larger banks are more likely to fail. They justify their results with the assumption that there is a moral hazard associated with an implicit TBTF policy which incentivised larger banks in Jamaica to take up riskier loan portfolios. However, in accordance to Arena (2008), they also observe that large banks are also more likely to be bailed out than closed. During the crisis period from 2007 to 2010, Cox and Wang (2014) also identify size as one of the causes of failed US banks. Besides, they also find that a high proportion of real estate loans and other uncollectible debt market investments make banks more likely to fail. Furthermore, the poor investment (loan) decision of the failed banks greatly contributed to income losses and was exacerbated by a low equity capital base insufficient to absorb the write-offs and losses of the US banks.

Based on relevant events in the course of the financial crisis starting in 2007 and subsequently fast growing literature on systemic risk in the US and EU, scholars in Latin America started (1) applying state-of-the-art measures of systemic risk (see Arias et al., 2010; Tabak et al., 2013a, b; Araújo and Leao, 2013) or even (2) proposed new systemic risk measures (see Léon and Machado, 2011; Léon et al., 2011; León and Murcia, 2012).

1) By applying the $\Delta$ CoVar methodology of Adrian and Brunnermeier (2011) mentioned above to the Colombian financial sector, Arias et al. (2010) show that financial corporations and financial corporatives mostly contribute to systemic risk. They also notice that risk co-dependency among entities significantly increases during distress periods. Tabak et al. (2013a) analyse the Brazilian financial system and find that the financial system's stress was higher during the crisis onset, but decreasing abruptly during the second half of 2008 (due to $70 \%$ interbank market's shrinkage). Additionally, they measure that the impact of the top 5 institutions is about $50 \%$ of all institutions' impact on the financial system's stability. This is in line with Rugitsky (2014) who argues that in the Brazilian case public banks had played a very important stabilizing role. Finally, Araújo and Leao (2013) apply the CoVaR measure for analysing the Brazilian banking sector between 2006 and 2012. They detect (in accordance with earlier literature discussed above) that big financial institutions have lower individual risk exposures, but pose higher systemic risks. However, they also note that a few smaller institutions are systemically relevant, too, and that state-owned institutions are less systemically important. Looking at the case of US bank holding companies Brunnermeier et al. (2011) find - comparable to the case of Brazil - that the CoVaR measure for systemic risk contribution is high for small banks with low market capitalisation.

2) In a series of works, Léon et al. (see reference list) use data of the Colombian interbank payment systems to propose an application of (network) techniques (such as the fuzzy logic inference system and the principal component analysis which are rather non-orthodox for economic analysis) for the identification of systemic risks. Their main findings are that only few 
financial institutions pertain to the high or very high categories of systemic importance and that non-banking financial firms are among the most systemically important financial institutions in Colombia. Furthermore, they stress the importance of connectedness on systemic importance, followed by size and substitutability.

Recent works since 2010 are limited to one single national financial market in Latin America (Colombia, Brazil, Chile), and therefore deliver little comparative results. Only Tabak et al. (2013b) - in a paper that is more focused on the relation between competition and stability in the banking sector - cover a wide range of 17 Latin American countries finding that bigger banks are more cost efficient and do not appear to be taking riskier position in relation to their smaller counterparts. Looking at banks in the European Union, Fiordelisi and Salvatore (2014) provide evidence in line with the competition-stability view proposed by Boyd and De Nicolò (2005), meaning that there is a positive relationship between market power and systemic risk. Another exception from the main focus on systemic risk is ChanLau (2012) who observes a positive influence of dynamic loan provisions on Chilean banks' solvency and bank business procyclicality. However, one similar result that all the Latin America papers presented have in common, is the particular high influence of macroeconomic/policy factors on banking systems' stability and the extent of the impact large failing financial institutions have on the financial system. ${ }^{3}$ It appears that in more developed countries like the US and the European Union member states, this strong dependence of macroeconomic/policy factors cannot be observed in most cases.

\section{ASSESSING REGULATORY INNOVATIONS DEALING WITH SIFIS IN LATIN AMERICA}

\section{Regulatory innovation in economic theory}

Usually, innovations are discussed as part of firms' policies. Going back to the famous contributions of Schumpeter in particular, innovations are regarded a core part of entrepreneurial activity. Besides their seminal meaning, Schumpeter also elaborated a systematisation (see e.g. Schumpeter, 1934), distinguishing (1) product innovation, (2) process innovation, (3) market innovation (i.e., new sales or supply opportunities), and (4) organisational innovation (in a commercial, financial, or legal sense). On the one hand, it might be useful to distinguish between innovation in goods and services, financial innovation, and regulatory innovation. Schumpeter focused on the first kind as an engine of market process and growth. In contrast, financial innovation can be understood as a way to improve financial relationships

\footnotetext{
${ }^{3}$ See particularly Arena (2008), Daley et. al (2008), Léon \& Machado (2011), Arias et al. (2010), Tabak et al. $(2013 \mathrm{a} / \mathrm{b})$.
} 
so that financial policy better contributes to firms' profits. In particular the aiming at positive leverage/debt structure effects, often by bypassing existing regulation, can support a financial crisis. Finally, regulatory innovation (related to the financial sector) can be seen as a way to cope with an ever changing financial sector, but it can also lead to confusion as it implies changes in the rules of the game for different reasons. On the other hand, Schumpeter's systematisation is so universal that it is applicable to all kinds of innovation, in particular since it has been shown that actors who set or/and execute rules or standards represent a special kind of entrepreneur, too. To reach their individual goals (like enhanced salary, responsibility, staff size, or other), politicians and bureaucrats act as political and bureaucratic entrepreneurs (explicitly, see e.g. High and Pearce, 1993; also North, 1990) who might as well try to be innovative, i.e., to introduce regulatory innovations. Urgency and opportunity to react to events unfolding by adjusting the regulatory framework seems particularly promising in times of crises, so that patterns of crisis-driven regulation can be observed on a regular basis (on the recent crisis, see Cunningham and Zaring, 2009). In fact, the characteristic interplay of financial and regulatory innovation has even been declared a "regulatory dialectic" (see Kane, 1988).

Consequently, the recent financial crises have fuelled reactions of rule makers and regulators, leading to considerable institutional change. Among numerous (re-) regulations, a rather new regulatory approach towards SIFIs has evolved. Regarding the Schumpeterian system, it is based on a market innovation, as a new field or segment has been identified to which regulation is applied (Schumpeter, 1934). Furthermore, this regulation contains new kinds of rules (resembling product innovation) and procedures. At least in some parts of the world, SIFI-regulation will be conducted by newly founded organizations. Thus, the regulation of SIFIs could be innovative in any of the Schumpeterian respects. Hereafter, we analyse the respective institutional change that could be observed in Latin America.

\section{Regulatory innovation in the current international framework}

National and international policy-makers are pointing out three starting points for future SIFI-regulation: (1) information systems, (2) international cooperation, and (3) enhanced (i.e., stricter) macro-prudential regulation (Yellen, 2011; GCEE, 2010; FSB, 2011).

1) Further development of information systems (qualitative and quantitative data) will help regulators and market participants to focus on systemic risks. Surprisingly, most of the data that regulators use for state-of-the-art assessments of systemic importance is not publicly available. Even some data that regulators require now has never been compiled by the respective financial institutions before. ${ }^{4}$

\footnotetext{
${ }^{4}$ To address the data lack, the FSB Data Gaps Initiative is currently working out a common data template for G-SIBs, see FSB (2013).
} 
2) International cooperation among regulators is essential, since SIFI-insolvencies (and their external negative effects) go across national boundaries: up to now, national regulators have only been acting regarding to their national interest. ${ }^{5}$ The financial shock after Lehman's failure consequently forced heads of states or governments to impose a reciprocal obligation to bail out national banks - to the disadvantage of national budgets and, finally, taxpayers. This shows that a proper handling of negative external effects can only be achieved by close international cooperation among regulators.

3) A SIFI-special macroprudential regulation was one of the first steps regulators took after realizing the significance of SIFIs. In general, macroprudential SIFI regulation is targeting at (a) the reduction of the probability of failure of SIFIs by increasing their loss absorbency, and (b) the reduction of the extent/impact a failing SIFI can have, by improving global recovery and resolution frameworks (IAIS, 2013).

In the following, we analyse regulators' initiatives on the reduction of (a) the probability of failure, and (b) the macroeconomic impact of a failing SIFI on the economy as a whole. The international standard setter Financial Stability Board $(\mathrm{FSB})^{6}$ has made important progress in developing indicators to measure systemic importance of financial institutions. The FSB as the main supranational institution to monitor and give recommendations on the global financial system defines systemically important financial institutions - making use of the former TBTF-concept - as institutions "that are perceived as not being allowed to fail due to their size, interconnectedness, complexity, lack of substitutability or global scope" (BCBS, 2013, p. 1). Unlike scholars who use more or less theoretically founded models, politicians and regulators prefer indicator based measurement approaches that comprise of a set of weighted indicators referring to an institution. Not surprisingly, policymakers have been satisfied to determine systemic importance almost exclusively with accounting information up to now (Bongini and Nieri, 2014).

On the international level, policymakers distinguish between the identification of global systemically important banks (G-SIBs), insurers (G-SIIs) and non-bank non-insurer financial institutions (NBNI G-SIFIs). The Basel Committee on Banking Supervision (BCBS) together with the FSB worked out an indicator-based measurement approach for the determination of G-SIBs. The idea is to measure global systemic importance in terms of the impact that a bank's failure can have on the global financial system, rather than assessing the risk that a failure can occur. Twel-

\footnotetext{
${ }^{5}$ In the case of Lehman Brothers, the US treasury department still believed that British Barclays bank would take over Lehman and prevent insolvency, until UK government refused to agree to the takeover in the last moment (see GCEE, 2010).

${ }^{6}$ The FSB located at the BIZ in Basel monitors and sets standards for the global financial system. It was founded after the G20 summit 2009 in London and comprises representatives from the G20 as well as other transnational institutions such as the IMF (International Monetary Fund).
} 
ve bank specific indicators are used to measure cross-jurisdictional activity, size, interconnectedness, substitutability and complexity of banks (see Table 1).

Table 1: FSB Indicator-based measurement approach for G-SIBs

\begin{tabular}{llc}
\hline \multicolumn{1}{c}{ Category } & \multicolumn{1}{c}{ Individual indicator } & $\begin{array}{c}\text { Indicator } \\
\text { weighting }\end{array}$ \\
\hline $\begin{array}{llc}\text { Cross juris-dictional } \\
\text { activity }\end{array}$ & Cross-jurisdictional claims & $10.00 \%$ \\
Size & Cross-jurisdictional liabilities & $10.00 \%$ \\
& Total exposures as defined by Basel III leverage ratio & $20.00 \%$ \\
Interconnected-ness & Intra-financial system assets & $6.67 \%$ \\
& Intra-financial system liabilities & $6.67 \%$ \\
Substitutability/ & Securities outstanding & $6.67 \%$ \\
institution infrastructure & Paysets under custody & $6.67 \%$ \\
& Transactions in debt and equity markets & $6.67 \%$ \\
Complexity & Notional amount of OTC derivatives & $6.67 \%$ \\
& Level 3 assets* & $6.67 \%$ \\
& Trading and available-for-sale securities & $6.67 \%$ \\
\hline
\end{tabular}

Source: BCBS (2013), p. 6.

* Level 3 assets are assets whose valuation relies on internal valuation models and unobservable inputs such as managers' assumptions and estimates (IFRS 13 Fair Value Measurement).

Starting with the financial year-ends of 2013, banks worldwide that show an exposure exceeding EUR 200 billion (as measured for Basel III leverage ratio calculation) will have to publicly disclose the 12 indicators used in the assessment methodology. ${ }^{7}$ Each year, the 75 largest banks in terms of leverage ratio exposure (similar to total assets), last year's G-SIBs, and banks that have been added by qualitative supervisory judgement are ranked. The major shortfalls of this approach are a lack of scientific basis (why twelve indicators from five groups with different weighting?) and a lack of consistent and high quality data (e.g., considering jurisdictional and accounting differences, non-availability of data in the banks' management information system). The FSB annually publishes a list of the first 30 banks in the ranking and allocates them to (currently) five buckets. ${ }^{8}$ Based on the bucket each G-SIB has to fulfil a certain additional tier-1-ratio capital requirement $\frac{\text { commom equity Tier } 1}{\text { risk weighted assets }}$ as a measure for higher loss absorbency. After an introduction phase, G-SIBs of the first bucket are required to maintain a total tier-1-ratio of $7 \%(6 \%$ Basel III requirement $+1 \%$ additional G-SIB requirement) from 2019 onwards. If

\footnotetext{
${ }^{7}$ As a consequence of requesting reports on exposures as defined by Basel III the FSB simultaneously enforces or at least implicitly assumes the application of the organisationally related BCBS's regime.

${ }^{8}$ The number of G-SIBs, and their bucket allocations, will evolve over time as banks are supposed to react to connected regulatory incentives, see BCBS (2013).
} 
the higher loss absorbency requirement is breached, the bank has to agree to a capital remediation plan (e.g., limitations on dividend pay-out: BCBS, 2013).

\begin{tabular}{|c|c|}
\hline Bucket & $\begin{array}{l}\text { Higher loss absorbency requirement: } \\
\qquad \frac{\text { commom equity Tier } 1}{\text { risk weighted assts }}\end{array}$ \\
\hline 5 & $3.5 \%$ \\
\hline 4 & $2.5 \%$ \\
\hline 3 & $2.0 \%$ \\
\hline 2 & $1.5 \%$ \\
\hline 1 & $1.0 \%$ \\
\hline
\end{tabular}

Source: BCBS (2013), p. 12.

There are two main areas of concern for the FSB-approach. The first concern is regarding the G-SIB-assessment: financial accounting data is used annually, and accounting standards are discretionary. It is not clear why exactly twelve indicators from five categories have been chosen (see Table 1). The second concern goes towards the G-SIB-regulation in form of a "buffer-on-a-buffer". A higher common equity ratio may neither incentivise banks to proactively manage risk or to become less systemically important nor improve banks' resilience and systemic risk contribution. To comply with the higher loss absorbency requirement, banks can try to capitalise retained earnings or raise new equity. But they can likewise reduce risk weighted assets. That would force them to reduce lending and trading activity or to shift business off their balance sheets. While the FSB approach is increasingly gaining importance, there is currently no designated G-SIB headquartered in Latin America. National supervisory authorities in Latin America, however, may adopt some of the proposals from the international level.

\section{Regulatory innovations aiming at SIFIs in Latin America}

Only recently, the regulation of SIFIs is receiving particular attention from financial supervisors and central banks in Latin America. This is not least attributable to the fact that Latin American banking systems and the overall economies had been less negatively influenced by the turmoil of the last financial crisis and no SIFI had to be bailed out in Latin America. A new concern of the authorities with systemic risks is emerging. While financial systems in Latin America remained underdeveloped in terms of size and complexity of products so far, a wide variety of financial intermediaries already operates in most countries. Large cross border conglomerates with complex structures dominate the landscape in several countries. Because of their size and interconnectedness, they can be considered systemically important already (Gutierrez and Caraballo, 2011).

Now, one of the major steps on the road to systemic oversight in Latin Amer- 
ican countries is boosting supervisory capacity and human resources. Issues related to the supervisory architecture appear relevant as well. The World Bank Regulation and Supervision Survey 2012, which captivates by providing comparable worldwide data on national financial (SIFI) regulations that are at their initial stages and usually not published/available for externals, has been supplemented by new questions on systemic supervision and contains answers from regulators of 16 Latin American countries (for an overview see Online Appendix Table 1).

About three-quarters of the surveyed jurisdictions state to have a specialized department in their supervisory agency dealing with financial stability and systemic supervision. In assessing systemic risk, those regulators consider a variety of indicators, mentioning most frequently bank capital and liquidity ratios, growth in bank credit, composition of bank loan portfolios, bank non-performing loan ratios, and bank provisioning ratios. All agencies receive sufficient input for a financial stability report, but only roughly two-thirds of all agencies publish a financial stability report (whereas three agencies with a specialized department on financial stability/systemic supervision do not publish such report). Stress tests - mostly at the bank level - are used by three-quarters of the surveyed supervisory agencies. One-third of those agencies conduct stress tests at the system wide level, too (see Online Appendix Table 1).

The Dominican Republic, Ecuador, El Salvador, Jamaica, Mexico, and Paraguay do not have installed a special SIFI-regulation yet. But the remaining roughly two thirds of the surveyed institutions (10 of 16) supervise SIFIs in a different way than non-systemic ones. However, those supervisors only have a few "special tools" to oversee and limit SIFIs' activities: additional capital requirements (comparable to the BCBS requirements), asset/risk diversification requirements, restrictions/limits on activities, closer/more frequent supervision. Those tools are rather classical. SIFI-specific tools (e.g., restrictions on the group's legal structure, restrictions on the institution's size, additional bank levies) are not implemented so far.

\section{CONCLUDING REMARKS}

The years preceding the world financial crisis that started in 2007 have been characterised as a period of deregulation and belief in the self-correcting functions of markets (Foley, 2013). Financial markets in particular were seen as "self-correcting systems that tended to return to a stable equilibrium before they could inflict widespread damage on the real economy" (Yellen, 2011, p. 1). However, during the crisis processes evolving, it became apparent that the trust put in market was too optimistic - as was the trust put in the (re-)actions of rule makers and regulators, so that especially SIFIs turned out to be a latent danger. Later, SIFIs have been perceived as being mainly a phenomenon of "highly developed" financial systems,

\footnotetext{
${ }^{9}$ For more information on survey's design, implementation and results see Čihák et al. (2012).
} 
such as can be found in the EU and the US. However, it cannot be precluded that SIFIs and the inherent danger of financial instability exist in Latin America, too. This we illustrated by a survey on the identification and regulation of SIFIs in Latin America. We find first approaches to that in science and regulatory practice among Latin American jurisdictions.

Finally, Latin American countries have a much better foundation on which to build and deal with the new challenges of systemic oversight. The collaboration on the international level and the general acceptance of proposals issued by international standard setters among Latin American countries is promising and should increasingly bear fruit. However, this paper reveals several deficits in the regulatory and supervisory handling of those SIFIs in Latin America that are neither part of the banking nor the insurance sector. Future research should start from here.

\section{REFERENCES}

Acharya, Viral V., Biggs, John, Richardson, Matthew and Ryan, Steven (2009) “On the financial regulation of insurance companies”, Working Paper, NYU Stern School of Business.

Acharya, Viral V, Pedersen, Lasse, Philippon, Thomas and Richardson, Matthew (2010). "Measuring systemic risk", Working Paper, Federal Reserve Cleveland, 10/02.

Adrian, Tobias and Brunnermeier, Markus (2011). "CoVaR", NBER Working Paper 17454, Cambridge: National Bureau of Economic Research.

Agnoli, Myriam and Vilán, Diego (2008). "Financing trends in Latin America”, Basel: Bank for International Settlements, 36: 15-27.

Alali, Fatima and Romero, Silvia (2013). "Characteristics of failed U.S. commercial banks: an exploratory study”, Accounting and Finance, 53: 1149-1174.

Araújo, Gustavo and Leao, Sergio (2013). "Risco sistêmico no mercado bancário brasileiro - uma abordagem pelo método CoVaR”, Working Papers series 307, Brasilia: Central Bank of Brazil.

Arena, Marco (2008). "Bank failures and bank fundamentals: A comparative analysis of Latin America and East Asia during the nineties using bank-level data”, Journal of Banking \& Finance, 32: 299310.

Arias, Mauricio, Mendoza, Juan and Pérez-Reyna, David (2010). “Applying CoVaR to Measure systemic market risk: the Colombian case”, Working Paper, Bogotá: Banco de la Republica.

BCBS (2013). "Global systemically important banks: updated assessment methodology and the higher loss absorbency requirement”, Basel: Bank for International Settlements.

Benston, George (1998). "Regulating financial markets: a critique and some proposals”, Hobart Papers 135, London: Institute of Economic Affairs.

Billio, Monica, Getmansky, Mila, Lo, Andrew and Pelizzon, Loriana (2012). "Econometric measures of connectedness and systemic risk in the finance and insurance sectors", Journal of Financial Economics, 104: 535-559.

BIS, FSB \& IMF - Bank for International Settlement, International Monetary Fund, Financial Stability Board (2009).) "Guidance to assess the systemic importance of financial institutions, markets and instruments”, Report to the G-20 Finance Ministers and Central Bank Governors, Washington, D.C.: IMF.

Bisias, Dimitrios, Flood, Mark, Lo, Andrew and Valavanis, Stavros (2012). “A survey of systemic risk analytics", Annual Review of Financial Economics, 4 (1): 255-296. 
Bongini, Paola and Nieri, Laura (2014). "Identifying and regulating systemically important financial institutions”, Economic Notes by Banca Monte dei Paschi di Siena, 43: 39-62.

Boyd, John and De Nicolò, Gianni (2005). "The theory of bank risk taking and competition revisited" Journal of Finance, 60: 1329-1343.

Bresser-Pereira, Luiz Carlos and Gala, Paulo (2007). "Why foreign savings fail to cause growth", Brazilian Journal of Political Economy, 27 (1): 3-19.

Bresser-Pereira, Luiz Carlos (2010a). "The global financial crisis and a new capitalism?”, Journal of Post Keynesian Economics, 32 (4): 499-534.

Bresser-Pereira, Luiz Carlos (2010b). "The global financial crisis, neoclassical economics, and the neoliberal years of capitalism", Revue de la regulation, 7 (1): 2-29.

Bresser-Pereira, Luiz Carlos (2013). "How science goes wrong”, The Economist, Oct 19 ${ }^{\text {th }}$.

Brownlees, Christian and Engle, Robert (2012). "Volatility, correlation and tails for systemic risk measurement”, Working Paper, New York: Stern School of Business.

Brunnermeier, Markus (2009). "Deciphering the liquidity and credit crunch 2007-2008", Journal of Economic Perspectives, 23 (1): 77-100.

Brunnermeier, Markus, Dong, Gang and Palia, Darius (2012). “Banks' non-interest income and systemic risk”, AFA 2012 Chicago Meetings Paper.

Chan-Lau, Jorge (2012). "Do dynamic provisions enhance bank solvency and reduce credit procyclicality - A study of the Chilean Banking system", Journal of Banking Regulation, 13 (3): 178-188.

Čihák, Martin, Demirgüç-Kunt, Asli, Martínez, Maria and Mohseni-Cheraghlou, Amin (2012). "Bank regulation and supervision around the world - a crisis update", Policy Research Working Paper 6286, Washington, D.C.: The World Bank.

Cox, Raymond and Wang, Grace (2014). "Predicting the US bank failure: A discriminant analysis", Economic Analysis and Policy, 44: 202-211.

Crystal, Jennifer, Dages, Gerard and Goldberg, Linda (2001). "Does foreign ownership contribute to sounder banks in emerging markets? The Latin American experience”, Staff Report 137, New York: Federal Reserve Bank of New York.

Cunningham, L. A. and Zaring, David T. (2009). "The three or four approaches to financial regulation: a cautionary analysis against exuberance in crisis response”, George Washington Law Review, 78 (1): 39-113.

Dabrowski, Marek (2001). "The episodes of currency crisis in Latin American and Asian economies", Case Report 39, Warsaw: Center for Social and Economic Research.

Daley, Jeremy, Matthews, Kent and Whitfield, Keith (2008). “Too-big-to-fail: Bank failure and banking policy in Jamaica”, Journal of International Financial Markets, Institutions and Money, 18 (3): 290-303.

Diamond, Douglas (1984) “Financial intermediation and delegated monitoring”, Review of Economic Studies, 51, 393-414.

Diamond, Douglas and Dybvig, Philip (1983). “Bank runs, liquidity and deposit insurance”, Journal of Political Economy 91: 401-419.

Fenn, George and Cole, Rebel (1994). "Announcements of asset-quality problems and contagion effects in the life insurance industry”, Journal of Financial Economics, 35: 181-198.

Fiordelisi, Franco and Salvatore, Davide (2014).) "Competition and financial stability in European cooperative banks", Journal of International Money and Finance 45: 1-16.

Foley, Duncan (2013). "Rethinking financial capitalism and the 'information' economy”, Review of Radical Political Economics, 45 (3): 257-268.

FSB (2011). "Policy measures to address systemically important financial institutions”, Basel: Financial Stability Board.

FSB (2013). "FSB data gaps initiative: a common data template for global systemically important banks", Workshop with Industry, New York: Financial Stability Board. 
GCEE - German Council of Economic Experts (2010). “Annual Report 2010/2011: Chancen für einen stabilen Aufschwung", Wiesbaden: Federal Bureau of Statistics.

González-Hermosillo, Brenda, Pazarbaşioğlu, Ceyla and Billings, Robert (1997). "Determinants of banking system fragility: a case study of Mexico", Staff Papers - International Monetary Fund, 44 (3): 295-314.

Gutierrez, Eva and Caraballo, Patricia (2011). "Survey on systemic oversight frameworks in LAC: current practices and reform agenda", Policy Research Working Paper 5941, Washington, D.C.: The World Bank.

High, Jack C. and Pearce, Jack A. (1993). "Regulation as an entrepreneurs' process", Journal of Private Enterprise, 9 (2): 39-48.

IMF (2009). “Global financial stability report 2009”, World Economic and Financial Surveys, Washington, D.C.: International Monetary Fund.

Jobst, Andreas and Gray, Dale (2013). "Systemic contingent claims analysis - estimating market-implied systemic risk”, IMF Working Paper 13/54, Washington, D.C.: International Monetary Fund.

Kane, Edward J. (1988) "Interaction of financial and regulatory innovation", Amercian Economic Review (Papers \& Proceedings), 78: 328-334.

Kindleberger, Charles (2005). Manias, Panics and Crises: A History of Financial Crises, $5^{\text {th }}$ Edition, Hoboken: John Wiley \& Sons.

Léon, Carlos and Machado, Clara (2011). "Designing an expert knowledge-based systemic importance index for financial institutions”, Borradores de Economia 669, Bogotá: Banco de la Republica de Colombia.

Léon, Carlos, Machado, Clara, Cepeda, Freddy and Sarmiento, Miguel (2011). "Too-connected-to-fail Institutions and Payments System's Stability: assessing challenges for financial authorities”, Borradores de Economia 644, Bogotá: Banco de la Republica de Colombia.(644).

León, Carlos and Murcia, Andrés (2012). "Systemic importance index for financial institutions: A principal component analysis approach”, Borradores de Economia 741, Bogotá: Banco de la Republica de Colombia.

Lozano, Ignacio and Guarín, Alexander (2014). "Banking fragility in Colombia: An empirical analysis based on balance sheets", Esayos sobre Política Económica, 32 (75):), 48-63.

Minsky, Hyman (1975). “John Maynard Keynes”, New York: Columbia Press.

Minsky, Hyman (1982). "The financial instability hypothesis: capitalistic processes and the behaviour of the economy", In: Kindleberger, Charles P. and Lafargue, Jean-Pierre (eds.). Financial Crises: Theory, History and Policy, Cambridge: Cambridge University Press: 13-29.

Minsky, Hyman (1992). “The financial instability hypothesis”, Working Paper 74, Annandale-on-Hudson: Jerome Levy Economics Institute of Bard College.

Molina, Carlos (2002). "Predicting bank failures using a hazard model: the Venezuelan banking crisis", Emerging Markets Review, 3 (1): 31-50.

North, Douglas (1990). "Institutions, institutional change, and economic performance”, Cambridge: Cambridge University Press.

Rugitsky, Fernando Monteiro (2014). "Austeridade fiscal, recessão e desemprego não levam ao crescimento", Brasil de fato, Dec $15^{\text {th }}$.

Schumpeter, Joseph A. (1934). "The theory of economic development: An inquiry into profits, capital, credit, interest, and the business cycle", Cambridge: Cambridge University Press.

Skipper, Harold and Klein, Robert (2000). "Insurance in the public interest: the path towards solvent", Geneva Papers of Risk and Insurance, 25: 492-510.

Stallings, Barbara and Studart, Rogerio (2006).) "Finance for development: Latin America in comparative perspective", Washington D.C.: Brookings Institution Press.

Stern, Gary and Feldman, Ron (2004). "Too big to fail: The hazards of bank bailouts", Washington, D.C.: Brookings Institution Press.

Summe, Kimberly A. (2009). "Lessons learned from the Lehman bankruptcy”, In: Scott, Kenneth and 
Taylor, John (eds.). Ending Government Bailouts as We Know Them, Chapter 5, Stanford: Hoover Press: 59-105.

Tabak, Benjamin, Souza, Sergio and Guerra, Solange (2013a). "Assessing systemic risk in the Brazilian interbank market”, Working Papers Series 318, Brasilia: Banco Central do Brasil.

Tabak, Benjamin, Fazio, Dimas and Cajueiro, Daniel (2013b). "Systemically important banks and financial stability: The case of Latin America”, Journal of Banking \& Finance, 37 (10): 3855-3866.

Weiß, Gregor, Neumann, Sascha and Bostandzic, Dzenefa (2014). "Systemic risk and bank consolidation: International evidence”, Journal of Banking \& Finance, 40: 165-181.

Weistroffer, Christian (2011). "Identifying systemically important financial institutions (SIFIs)", Working Paper, Frankfurt: Deutsche Bank Research/M.

Yellen, Janet (2011). "Macroprudential supervision and monetary policy in the post-crisis world", $B u$ siness Economics, 46 (1): 3-12. 